\title{
The Distribution of Benefits from Improvements in Urban Air Quality ${ }^{1}$
}

\author{
David Harrison, JR. \\ Department of City and Regional Planning, Harvard University, \\ Cambridge, Massachusetts 02138 \\ AND \\ Daniel L. Rubinfeld \\ Department of Economics, Institute of Public Policy Studies, \\ University of Michigan, Ann Arbor, Michigan 48104 \\ Received December 7, 1977; revised May 1, 1978
}

\begin{abstract}
This paper analyzes the distribution of benefits from an air pollution control strategy for the Boston metropolitan area. Average benefits to seven income groups are measured by physical improvements in air quality and by dollar values, using housing value and health damage approaches to estimate willingness to pay. Benefits include those in the work environment as well as at home. Physical benefits at home are found to be greater for the poor rather than for the rich; when measured in monetary terms with workplace benefits included, however, the distribution is much less pro-poor.
\end{abstract}

\section{INTRODUCTION}

The 1970 Clean Air Act amendments established ambitious goals for improving urban air quality and mandated a number of mechanisms for achieving these goals. ${ }^{2}$ While compliance has lagged behind the original timetables, urban Americans are undoubtedly breathing better air. The programs, particularly those to reduce automobile emissions, have been expensive, however, and many question whether the benefits are commensurate with the costs. ${ }^{3}$ There is also concern that some strata of society may pay a disproportionate amount of the costs of control while others receive more benefits.

This paper focuses on the distribution of benefits from the federal automotive

1 The authors wish to thank Ben Dansker for his helpful research assistance; Marcia Fernald and Robert McDonald for their editorial help; and A. Myrick Freeman, Eugene Seskin and an anonymous referee for their very helpful substantive comments. Myrick Freeman's comments were especially relevant for the discussion of housing market valuation in Section 3 .

2 Public law No. 91-604 4 (a), 84 Sta. 1967 (1970). The provisions of the 1970 Amendments are summarized in Grad et al. [12].

${ }^{3}$ Recent major studies of the national costs and benefits of the automative emission control program include: Dewees [7], Grad et al. [12], Harrison [13], Jacoby and Steinbruner [17], and National Academy of Sciences [24]. Dorfman and Snow [8] and Harrison [14] estimate the distribution of the costs of auto emission control by income group. Dorfman [9] presents estimates of the distribution of costs and benefits for all environmental programs. 
emission control strategy in the Boston metropolitan area. ${ }^{4}$ Average benefits experienced by households in seven income groups are measured both by physical improvements in air quality and by dollar values, using two techniques-a housing value approach and a health damage approach - to estimate willingness to pay. Benefits include those in the work environment as well as at home.

Studies by Argonne (reported in [8]), Freeman [10], Harrison [13], Kruvant [20], and Zupan [39] indicate that the urban poor are exposed to worse air quality without pollution controls but benefit more than other groups when controls are instituted. Although Harrison [13] specifically considered the distribution of the benefits from the automotive emission control strategy, none of these analyses attempted to translate physical benefits into dollar measures of willingness to pay for clean air. Moreover, these previous studies estimated urban benefits obtained only where people live, not where they work.

This paper corroborates the conclusion that physical residential air quality benefits are greater for the urban poor than for the urban rich. When workplace benefits and differences in the valuation of physical benefits by income group are considered, however, the results are much less pro-poor: the absolute level of benefits, measured in dollars, in fact rises consistently and substantially with income. Only when expressed as a percentage of income are air quality benefits pro-poor.

\section{PHYSICAL AIR QUALITY BENEFITS}

Air quality varies a great deal across the 506 census tracts in the Boston metropolitan area. The meteorological model we use, which is calibrated to Boston area monitoring data, predicts an average nitrogen oxides (NOX) concentration of 5.6 parts per hundred million (pphm) with a standard deviation of $1.2 \mathrm{pphm} .{ }^{5}$ Although other pollutants show similar variations, each exhibits somewhat unique meteorological characteristics. ${ }^{6}$ We have focused on NOX because it is a major automobile pollutant and because its measurement is most appropriate to the meterological model we use.

Census data on household locations and incomes permit an estimation of average residential exposure to NOX by income group. ${ }^{7}$ Base year (1970) exposure levels, listed in Table I, indicate that lower income households on average are exposed to worse air quality, although the differences are not dramatic. Annual NOX concentrations range from $5.92 \mathrm{pphm}$ for households earning less than $\$ 3000$ to $4.99 \mathrm{pphm}$ for households earning more than $\$ 25,000$.

Table I also includes average NOX levels assuming that the automobile emis-

${ }^{4}$ Since this paper concerns Boston residents, it does not assess the distribution of benefits in smaller urban and non-urban areas. See Harrison [13] and Harrison [14] for estimates of the distribution of benefits in urban areas of different sizes and non-urban areas.

${ }^{5}$ The air quality data used in this study are obtained from the Transportation and Air Shed Simulation Model (TASSIM) developed by Gregory Ingram and others. We wish to thank Gregory Ingram, Gary Fauth and Eugene Kroch for making the TASSIM results available to us. For a description of the TASSIM model, see Ingram and Fauth [16].

${ }^{6}$ The other major pollutants for which federal air quality standards have been established under the 1970 Clean Air Act are carbon monoxide, hydrocarbons, photochemical oxidants, particulates and sulfur oxides. Carbon monoxide, hydrocarbons and photochemical oxidants are also autorelated pollutants. See Grad et al. [12], Chapter 2.

${ }^{7}$ U. S. Bureau of the Census [35]. 
TABLE I

Residence Air Quality Impacts by Income Group and Housing Tenure in Boston SMSA ${ }^{a}$

\begin{tabular}{|c|c|c|c|c|c|c|c|}
\hline & \multicolumn{7}{|c|}{ Income group (000s) } \\
\hline & $\$ 0-3$ & $\$ 3-5$ & $\$ 5-7$ & $\$ 7-10$ & $\$ 10-15$ & $\$ 15-25$ & $\$ 25+$ \\
\hline \multicolumn{8}{|c|}{ All Households } \\
\hline Base level & 5.918 & 5.867 & 5.793 & 5.590 & 5.324 & 5.123 & 4.989 \\
\hline Control level & 5.244 & 5.202 & 5.145 & 4.993 & 4.788 & 4.632 & 4.529 \\
\hline Benefits & 0.674 & 0.665 & 0.648 & 0.597 & 0.536 & 0.491 & 0.460 \\
\hline \multicolumn{8}{|c|}{ Owners } \\
\hline Base level & 5.340 & 5.292 & 5.282 & 5.163 & 5.036 & 4.924 & 4.844 \\
\hline Control level & 4.805 & 4.766 & 4.727 & 4.668 & 4.568 & 4.479 & 4.416 \\
\hline Benefits & 0.535 & 0.526 & 0.525 & 0.495 & 0.468 & 0.445 & 0.428 \\
\hline \multicolumn{8}{|c|}{ Renters } \\
\hline Base level & 6.161 & 6.143 & 6.066 & 5.951 & 5.812 & 5.756 & 5.800 \\
\hline Control level & 5.428 & 5.411 & 5.352 & 4.268 & 5.160 & 5.119 & 5.162 \\
\hline Benefits & 0.733 & 0.732 & 0.714 & 0.683 & 0.652 & 0.637 & 0.638 \\
\hline
\end{tabular}

${ }^{a}$ All impacts are expressed as NOX concentrations (24-hr annual average in parts per hundred million).

sion controls mandated by the 1970 Clean Air Act amendments are in effect. ${ }^{8}$ The final row lists average air quality benefits, calculated as the difference between base levels and control levels. Specifically, average benefits $\left(A B_{j k}\right)$ for each income class and tenure type were calculated from the formula:

$$
A B_{j k}=\sum_{i=1}^{N} H_{i j k}\left(\operatorname{NOX}_{i}{ }^{b}-\operatorname{NOX}_{i}{ }^{c}\right) / \sum_{i=1}^{N} H_{i j k}
$$

where

$H_{i j k}=$ the number of housing units of tenure type $k$ (owner, renter) in census tract $i$ that are occupied by a household in income class $j$.

$\mathrm{NOX}_{i}{ }^{b}=$ base level of NOX in pphm in census tract $i$.

$\mathrm{NOX}_{i}{ }^{c}=$ control level of NOX in census tract $i$.

$N=$ number of census tracts in Boston (506).

Two conclusions may be drawn from these results. First, the physical benefits of auto emission control in Boston are distributed in a pro-poor manner. ${ }^{9}$ Such benefits decline consistently as income incrcases, and range from $0.674 \mathrm{pphm}$ for households earning $\$ 3000$ or less to 0.460 for households earning more than $\$ 25,000$ per year. Households in the lowest income group will therefore, on average,

${ }^{8}$ The control level concentrations are calculated on the assumption that all cars on the road are manufactured to meet the stringent final emission standards mandated by the 1970 Clean Air Act and set administratively by the Environmental Protection Agency in 1971. See Harrison [14] for a summary of developments relating to federal automotive emission control.

${ }^{9}$ Low income households receive greater air quality benefits both because benefits decrease by income group for the owner and renter categories and because low income households are more heavily concentrated in the renter category. In the Boston SMSA, for example, 70.0 percent of households earning less than $\$ 3000$ rent their homes as compared to $16.0 \%$ for households earning more than $\$ 25,000$ per year. 
receive almost $50 \%$ greater benefits from the federal auto emission control program than households in the highest income group. Second, renter households in a given income group generally experience greater physical benefits than homeowners, a trend that reflects the greater concentration of rental units in central, highly polluted areas where the greatest improvement occurs. Distinguishing between tenure types is important since benefits which accrue to renters may eventually be captured by landlords in the form of higher rents; these changes in the distribution of benefits are considered in Section 3.

Benefits from cleaner air around one's home account for only part of the bencfits from improved air quality. Household members will also benefit from better air quality where they work, go to school, shop, and visit friends. Workplace benefits are likely to be the only other category we need to add, however, since shops, friends, and schools are usually close to home. Any systematic variation in the income profile of workers in various parts of the urban area would alter the distribution of benefits based solely on residence effects. For example, if highincome workers are more concentrated in the central city than high-income residents, the distribution of the combined work and residence benefits will be less pro-poor than that indicated in Table I.

Since the Census does not provide income profiles by workplace location, we developed these data from information on the employment mix by city and town and wage distribution by occupation group. Average workplace benefits $\left(A B W_{j}\right)$ for each income class were estimated from the formula:

$$
\mathrm{AB} W_{j}=\sum_{i=1}^{N} W B_{i j}\left(\mathrm{NOX}_{i}^{b}-\mathrm{NOX}_{i}^{c}\right) / \sum_{i=1}^{N} W B_{i j}
$$

where

$W B_{i j}=$ number of households in income class $j$ working in census tract $i$, which in turn was calculated from the following formula:

$$
W B_{i j}-\sum_{j=1}^{3} \operatorname{HT}_{f}\left(\sum_{m=1}^{8} \mathrm{EM}_{i m} \cdot \operatorname{TAM}_{j m f}\right)
$$

where

$\mathrm{HT}_{f}=$ fraction of households of type $f$ (family, male-head, female-head), assumed equal for all tracts. In $1970,82.8 \%$ of households were families, $8.0 \%$ were headed by a male unrelated individual, and $\mathbf{9 . 2}$ were headed by a female unrelated individual.

$\mathrm{EM}_{i m}=$ number of employees in job category $m$ that work in tract $i$. The eight job categories are the following : mining; construction; manufacturing ; transportation; communication and utilities; wholesale and retail; finance, real estate, and insurance; and services.

$\mathrm{FAM}_{j m f}=$ proportion of employees of family type $f$ employed in job category $m$ that are in income class $j$.

Average workplace benefits, shown in Table II, are roughly the same for workers in all household income groups. Combined work and residence benefits are, therefore, less pro-poor than if only residence benefits were included.

While the distribution of workplace benefits reported here is plausible, the results should be viewed as tentative because of several assumptions embedded 
TABLE II

Workplace Air Quality Impacts by Income Group in Boston SMSA ${ }^{a}$

\begin{tabular}{lccccccc}
\hline & \multicolumn{7}{c}{ Income Group (000s) } \\
\cline { 2 - 8 } & $\$ 0-3$ & $\$ 3-5$ & $\$ 5-7$ & $\$ 7-10$ & $\$ 10-15$ & $\$ 15-25$ & $\$ 25+$ \\
\hline Base level & 5.790 & 5.790 & 5.783 & 5.782 & 5.786 & 5.794 & 5.831 \\
Control level & 5.174 & 5.173 & 5.169 & 5.169 & 5.173 & 5.178 & 5.199 \\
Benefits & 0.616 & 0.617 & 0.614 & 0.613 & 0.613 & 0.616 & 0.632 \\
\hline
\end{tabular}

${ }^{a}$ All impacts are expressed as NOX concentrations (24-hr annual average in parts per hundred million).

in the formula:

1. Since the employment data were given by city and town rather than by rensus tract, we assumed that employment within a jurisdiction was evenly distributed to all census tracts. For Boston and Cambridge, however, we used maps and more detailed information on employment locational patterns to allocate workers.

2. In estimating the number of households of each family type in each income class working in each census tract (the parenthetical expression in Eq. (3)), we assumed that observations on FAM given by the Census for heads of households in the Boston SMSA applied to all family workers in all census tracts.

3. The proportion of employees in each family type, HT, was assumed to be the same for all employment categories and all census tracts, and thus independent of job category and location.

\section{THE DOLLAR VALUE OF AIR QUALITY BENEFITS}

Estimation of physical benefits is the first step in determining the dollar value households are willing to pay for improved air quality. We employed both a housing value approach and a health benefit approach to generate dollar values for the air quality benefits by income group. The housing value approach was used to estimate benefits both at home and at work.

A preliminary issue to be addressed, however, is whether and to what extent housing value benefits overlap the benefits obtained from health studies. In order for the housing value approach to measure willingness to pay for decreases in air pollution, it is not necessary that households possess detailed knowledge of the specific impacts of air pollution. It is simply necessary that some households will pay more for houses in less polluted areas than for equivalent housing in highly polluted areas. The double-counting issue relates to the reasons households seek to avoid polluted areas: they are probably aware, to some extent at least, of the extra cleaning and maintenance costs associated with poor air quality, as well as its associated odor, eyc irritation, and lack of visibility; what is not so clear is the extent to which health damages are considered. If households respond to known adverse health effects or simply expect health effects to be serious in highly polluted areas without specific knowledge, the two benefit estimates are likely to overlap substantially. ${ }^{10}$ Rather than combine the two benefit estimates

${ }^{10}$ Of course, if individuals are substantially risk averse and misperceive the possible health damages from air pollution, estimates of aggregate benefits may be substantially overstated. The issue of whether double-counting occurs when results from the property value and health approaches are added together is discussed in National Academy of Sciences [23] and in Rubinfeld [29]. 


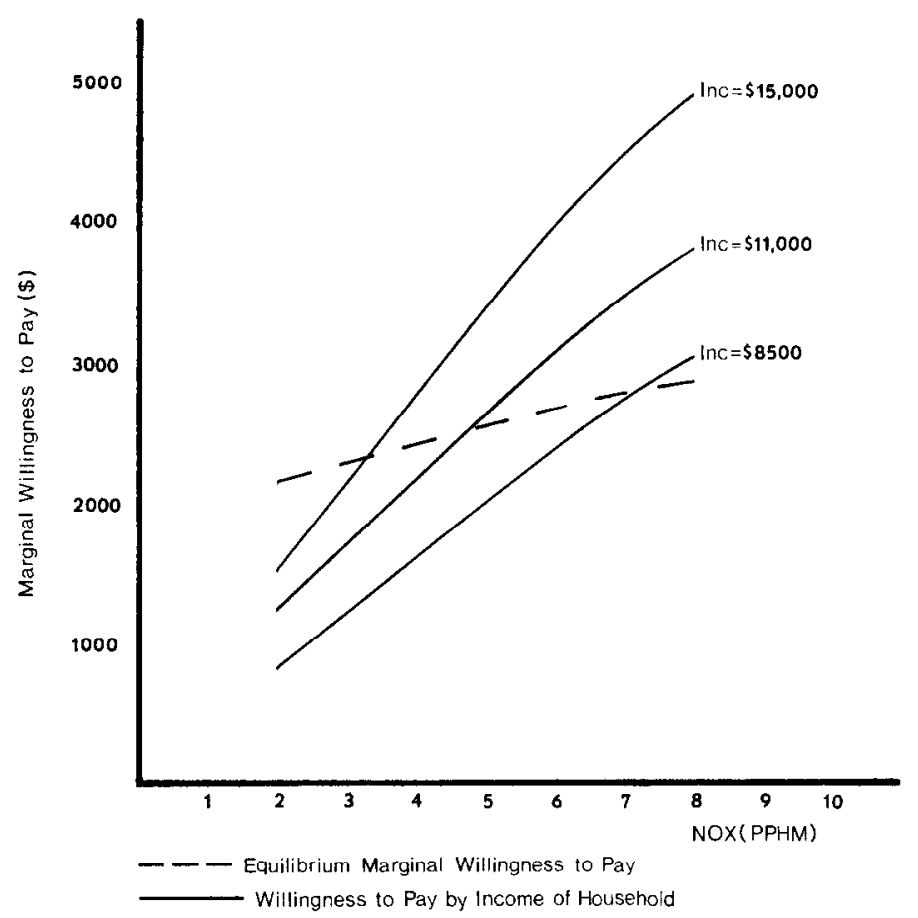

FIG. 1. Willingness to pay for clean air.

arbitrarily to estimate total willingness to pay, we have chosen to report each separately in this paper.

\section{Valuing Residential Benefits}

In a previous study we used housing market data for Boston to determine the relationship between households' willingness to pay for marginal improvements in air quality (i.e., the dollar value placed on a one unit decrease in NOX and other air pollutants) and the level of air quality and income. ${ }^{11}$ The estimation procedure involves two stages. In the first stage housing values are regressed on structural characteristics, neighborhood characteristics, measures of accessibility, and measures of air pollution. The change in housing values associated with a unit reduction in air pollution provides a measure of the market's valuation of the marginal willingness to pay for improved air quality. If the housing value equation were linear in each of the attributes, the estimated marginal willingness to pay would be identical at all locations. Because the housing value equation was found to be nonlinear, however, the market equilibrium marginal willingness to pay varies spatially as depicted in Fig. 1. The results suggest that in equilibrium the implicit marginal price on air quality increases with the level of air pollution concentration. If all households had identical willingness-to-pay functions, we might interpret these results as describing households' demands for clean air. We chose instead to allow for the possibility that households' demands might vary because

"Harrison and Rubinfeld [15]. See Nelson [24] for a similar study using data for Washington, D. C. See Rubinfeld [29] for a discussion of the difficulties of distinguishing the benefits of automotive emission control from the benefits of stationary source control in these property value studies. 
TABLE III

Dollar Value of Residence Benefits by Income Ciroup

\begin{tabular}{|c|c|c|c|c|c|c|c|}
\hline & \multicolumn{7}{|c|}{ Income group $(000 \mathrm{~s})$} \\
\hline & $\$ 0-3$ & $\$ 3-5$ & $\$ 5-7$ & $\$ 7-10$ & $\$ 10-15$ & $\$ 15-25$ & $\$ 25+$ \\
\hline \multicolumn{8}{|c|}{ Case I } \\
\hline Owners & 74 & 73 & 73 & 69 & 66 & 67 & 76 \\
\hline Renters & 98 & 98 & 98 & 85 & 92 & 93 & 111 \\
\hline $\begin{array}{l}\text { Average benefit per } \\
\text { household }\end{array}$ & 91 & 90 & 90 & 83 & 76 & 73 & 81 \\
\hline$\%$ of income & 5.1 & 2.3 & 1.5 & 0.98 & 0.61 & 0.37 & 0.27 \\
\hline \multicolumn{8}{|c|}{ Case II } \\
\hline Owners & 74 & 73 & 73 & 69 & 66 & 67 & 76 \\
\hline $\begin{array}{l}\text { - Inereased rental income } \\
\text { (per household) }\end{array}$ & 24 & 26 & 30 & 43 & 55 & 61 & 62 \\
\hline $\begin{array}{l}\text { Average benefit per } \\
\text { household }\end{array}$ & 46 & 50 & 55 & 75 & 96 & 111 & 126 \\
\hline$\%$ of income & 2.6 & 1.3 & 0.91 & 0.88 & 0.77 & 0.56 & 0.42 \\
\hline
\end{tabular}

a Case I : Renters receive all of the benefits associated with their cleaner environment. Case II : All renter benefits are capitalized into higher housing values and distributed among owners of rental property.

of difference in tastes and/or income. In the second stage of the estimation procedure, we therefore regressed the estimated implicit market price at each location on air quality, income and other taste variables. The results shown in Fig. 1 assume that houschold demands vary only with income and air quality.

We concluded that for households in a given income class the marginal valuation of air quality improvements varies positively with air pollution levels. In addition, for a given level of air pollution, the marginal willingness to pay for an improvement in quality varies positively with income. ${ }^{12} \mathrm{~A}$ corollary is that for all income groups, other things equal, the physical benefits of cleaning the air in highly polluted central areas are more highly valued than those from improving air quality in relatively clean areas.

Using the residence benefits per household that were estimated in the previous section and the willingness-to-pay function depicted in Fig. 1, we calculated the annual willingness to pay for each income group; these estimates are displayed in Table III. Since some or all benefits originally received by tenants may be capitalized into higher housing prices, we obtained results for two situations: in Case I, renters retain all benefits of the improvement in air quality; in Case II, the willingness to pay of existing tenants is assumed to be capitalized into higher rents with all benefits thus accuring to the property owners.

Average benefits per household for owners and renters in each income group under Case I were obtained from the formula:

$$
V \mathrm{AB}_{j k}=\sum_{i=1}^{N} H_{i j k} V_{i j} / \sum_{i=1}^{N} H_{i j k}
$$

${ }^{12}$ A positive relationship between willingness to pay for clean air and household income is expected, since it merely indicates that air quality is a normal good. Translating the Harrison and Rubinfeld results into elasticities generates an income elasticity of demand for clean air of 1.2 (and a price elasticity of -1.2 ), implying that clean air is in fact a luxury good. 
where

$V \mathrm{AB}_{j k}=$ average capitalized benefits for a household in income class $j$ of tenure type $k$.

$H_{i j k}=$ number of housing units of tenure type $k$ in census tract $i$ that are occupied by households in income class $j$.

$V_{i j}=$ average willingness to pay for air quality benefits (base level minus control level) of a household in income class $j$ residing in census tract $i$. $V_{i j}$ was computed as follows:

$$
V_{i j}=\int_{\mathrm{Nox}_{i}^{b}}^{\mathrm{Nox}_{i}{ }^{c}} f\left(\mathrm{NOX}_{i}, \mathrm{INC}_{j}\right) d\left(\mathrm{NOX}_{i}\right)
$$

$f\left(\mathrm{NOX}_{i}, \mathrm{INC}_{j}\right)=\exp \left[-3.10+0.87 \log \left(\mathrm{NOX}_{i}\right)+1.00 \log \left(\mathrm{INC}_{j}\right)\right]$

$\mathrm{INC}_{j}=$ average income of households in income class $j$.

Annual benefits were then obtained by dividing capitalized benefits by 10 . In Case I benefits for each income group are simply a weighted average of the owner and renter figures, where the weights are the fraction of households in the two tenure classes.

In Case II, the value of per household capitalized benefits is based on direct owner benefits $\left(A B_{j}{ }^{\circ}\right)$ and increased rental income $\left(\mathrm{CRI}_{j}\right)$, i.e.,

$$
V A B_{j}=\frac{\mathrm{CRI}_{j}+\left(H_{j}{ }^{0}\right)\left(\mathrm{AB}_{j}{ }^{0}\right)}{H_{j}}
$$

where

$H_{j}=$ total number of households in income class $j$.

$H_{j}{ }^{0}=$ total number of owner units occupied by income class $j$.

$\mathrm{AB}_{j}{ }^{0}=$ average direct owner benefits for households in income class $j$.

$\mathrm{CRI}_{j}=$ increased rental income to households in income class $j$.

The values for $C R I_{j}$ are calculated as follows:

$$
\mathrm{CRI}_{j}=\frac{\left(A_{j}\right)(\mathrm{TU})(\mathrm{WA})}{H_{j}}
$$

where

$A_{j}=$ fraction of rental units owned by individuals in income class $j$ (see Table VIII).

$\mathrm{TU}=$ total rental units in Boston SMSA (see Table VIII).

$\mathrm{WA}=$ average willingness to pay for air quality for all renter households.

Dollar benefits under Case I are slightly pro-poor: households earning less than $\$ 3000$ per year receive $\$ 91$ per year in benefits while households in the $\$ 15,000$ to $\$ 25,000$ range receive only $\$ 73$. Households in the highest income group, however, obtain average benefits valued at $\$ 81$ per year. When expressed as a percentage of income, benefits are more pro-poor, ranging from $5.1 \%$ for the lowest income group to $0.27 \%$ for the wealthiest group.

Benefits are less pro-poor under Case II since tenant benefits are passed on to rental property owners who tend to have higher incomes than tenants. Households earning less than $\$ 3000$ per year on the average obtain $\$ 24$ per year from 
increased rents due to air quality improvements, while households earning more than $\$ 25,000$ receive an average of $\$ 62$ per year as owners of rental property. Average benefits per household under Case II range from $\$ 46$ for the lowest income group to $\$ 126$ per year for the more than $\$ 25,000$ group. Expressed as a percentage of income, however, benefits are still markedly pro-poor: $2.6 \%$ for the poorest households and 0.42 for the wealthiest.

The Case II results are, of course, quite sensitive to our underlying assumptions. Two of the most critical issues are:

1. We have implicitly assumed that households will not relocate after the air quality improvement. General equilibrium adjustments in the housing market would complicate the estimation of landlord benefits since rents may change to reflect the valuations of future rather than existing residents. For example, air quality improvements in the central city may encourage high income households to replace low income residents, driving up rents to a level that reflects the high rather than low income valuation of air quality benefits. Landlords would thus obtain greater benefits than estimated in Case II.

2. Since data on the income profile of landlords are very difficult to obtain, we based our estimates on the proportions of owners in various occupation groups given by Sternlieb for New York and Newark. ${ }^{13}$ We converted these figures to income group estimates using U. S. Census data on the income profiles of each occupational group. We assumed that Boston's rental property owners are similar to those in Newark and New York, and that average census figures relating income to occupation are appropriate for Boston.

Myrick Freeman has raised an interesting issue regarding the Case I pattern of benefits by income group, in particular the larger average bencfits for the over $\$ 25,000$ group compared to the $\$ 15,000$ to $\$ 24,999$ group. Our previous disuscsion suggests two reasons why average benefits for the high income groups should be smaller than for low income groups. In the first place, higher income groups on average live in suburban areas with relatively low levels of air pollution, and thus in equilibrium their marginal willingness to pay should be lower than that of poorer households. Second, we have shown that high income households experience a smaller physical improvement in air quality than do low income households. The expected outcome, given these two factors, is illustrated in Fig. 2, which shows willingness to pay curves for an average high income and low income household. The integral measuring the high income benefit (area A) is substantially smaller than that representing the low income benefit (area B). Predictions of the pattern of average benefits by income group based on this reasoning are borne out in Table III for all groups except the highest.

The apparent contradiction can best be explained by reviewing how we calculated benefits for each income group. We used census tract median income data to estimate the households' willingness-to-pay functions. To estimate average monetary benefits for each income class, however, we used data on the number of households in each income group in each census tract. For the households in a given income group that reside in each census tract, we integrated the willingness to pay function from the pre- to the post-clean-up levels, using the willingness to pay function evaluated at the average income of that income class. The average

${ }_{13}$ See Sternlieb [32] and Sternlieb [33].

14 This diagram and much of the analysis which follows were supplied by Freeman. 


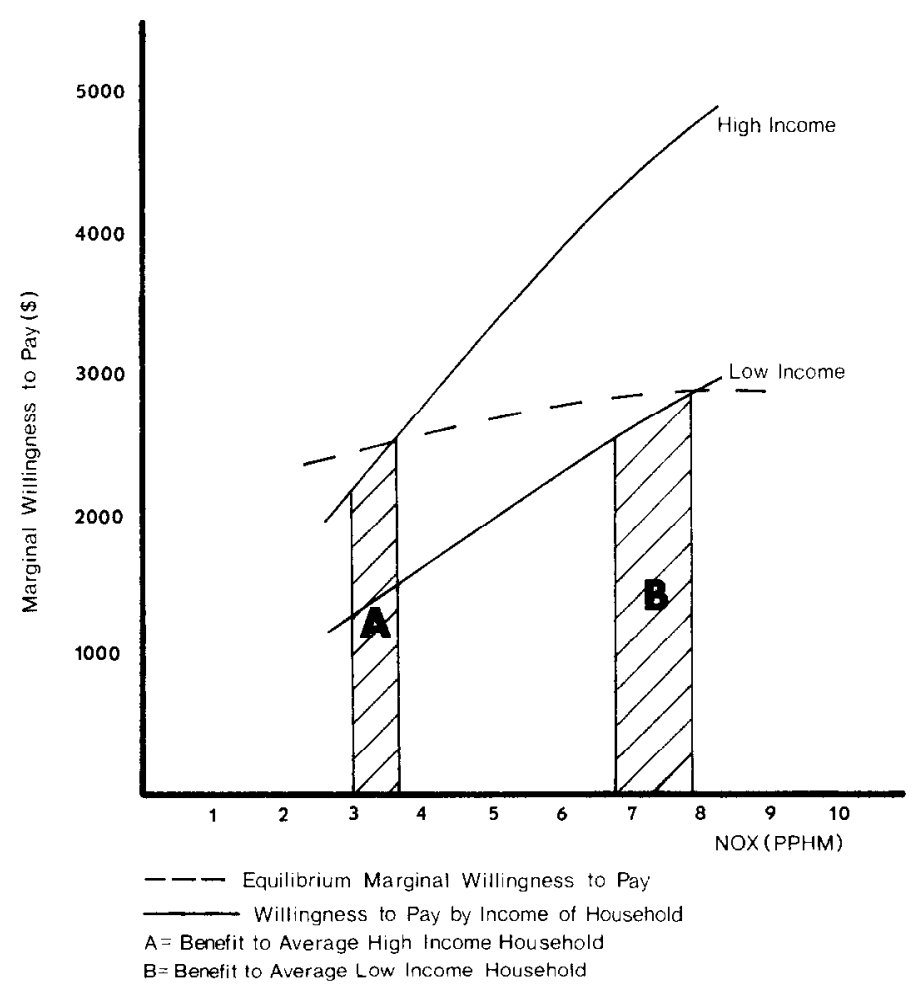

FIG. 2. Iifferences in average air quality benefits by income class.

figure for each income group given in Table III thus reflects estimates of the willingness to pay at all locations in the Boston area. Fig. 3 shows the willingnessto-pay function for a high income group and the benefits obtained by two members. The household living in the relatively clean area shows the expected result (i.e., small dollar benefits). A number of high income households live in areas with poor air quality, however, and thus received the large physical benefits shown for the second household. The dollar amount these households are willing to pay for air quality improvements is very large. For the highest income group, these benefits are so substantial that they outweigh the relatively low benefit estimates obtained by members living in cleaner areas.

To check this hypothesis empirically, we examined the 86 census tracts in which NOX levels were more than one standard deviation higher than the average. While only $10 \%$ of high income $(\$ 25,000+)$ owner households were located in these highly polluted tracts, their average willingness to pay was $\$ 229$. In contrast, the average willingness to pay of the remaining $90 \%$ of these high income households was only $\$ 59$. These calculations indicate that it is the willingness to pay of high income households living in areas with high pollution levels that causes the average benefit to high income households to be so great.

While the above explanation explains the results in Table III, it does suggest two troublesome issues:

1. Our distributional estimates for very high income households are likely to be very sensitive to the specification of the willingness-to-pay function.

2. Why would high income households with high marginal valuations on 


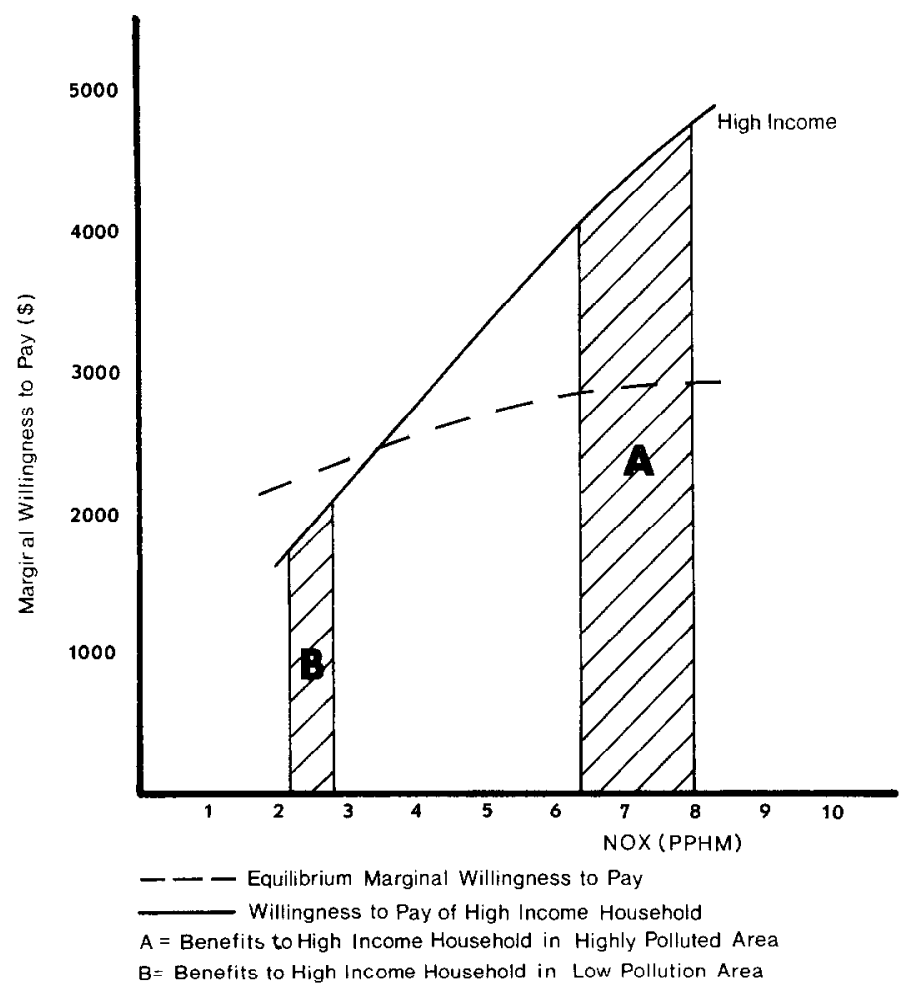

FIG. 3. Differences in air quality benefits of high income households by location.

clean-up choose to live in heavily polluted areas? One possible explanation is that they place high value on certain housing attributes available only in highly polluted areas. This suggests that we should consider estimating a system of demand equations for households of a given income class in which attribute demands may be interdependent. ${ }^{15}$ It is also possible, however, that households within a given income class have different tastes, in which case the willingnessto-pay functions have been misspecified. Of course, if this argument were taken to the extreme in which tastes varied systematically with air quality, it would be impossible to identify demand functions for clean air.

\section{Valuing Workplace Benefits}

Using the same willingness-to-pay functions, we calculated the value that Boston households place on air quality improvements at work. The first set of estimates in Table IV assume that workplace benefits are valued at the same rate as a residence benefits; in the second set, they are valued at only one-third

${ }^{15}$ In Harrison and Rubinfeld [15] we estimated a series of alternative air pollution attribute equations which included other housing attributes thought to be complimentary or substitutable with air quality. While the coefficients of the willingness-to-pay equation changed somewhat, the aggregate estimate of monetary benefits from pollution reduction hardly changed at all. We suspect that the same would be true for monetary benefits estimated for individual income classes.

${ }^{16}$ Myrick Freeman also suggested to us in correspondence that since housing attributes are not available in all possible combinations, hedonic price functions may not be defined throughout all of the attribute space, in which case the demand functions would not be continuous. If this were the case, our marginalist interpretation of the results might be seriously misleading. 
TABLE IV

Dollar Value of Workplace Benefits by Ineome Group ${ }^{a}$

\begin{tabular}{ccccccccc}
\hline & \multicolumn{7}{c}{ Income group (000s) } \\
\cline { 2 - 6 } & $\$ 0-3$ & $\$ 3-5$ & $\$ 5-7$ & $\$ 7-10$ & $\$ 10-15$ & $\$ 15-25$ & $\$ 25+$ \\
\hline & 17 & 34 & 50 & 67 & 105 & 169 & 260 \\
Dollar value & 0.94 & 0.85 & 0.83 & 0.79 & 0.84 & 0.85 & 0.87 \\
\% of income & & & Case B & & & & \\
Dollar value & 6 & 11 & 17 & 22 & 35 & 56 & 87 \\
$\%$ of income & 0.33 & 0.28 & 0.28 & 0.26 & 0.28 & 0.28 & 0.29 \\
\hline
\end{tabular}

${ }^{a}$ Case $\mathrm{A}$ : worker benefits valued at residential rate. Case $\mathrm{B}$ : worker benefits valued at one third of residential rate.

of residence benefits because not all household members are employed and more time is spent at home than at work. Unlike residence benefits, air quality improvements at the workplace favor higher income households : benefits range from $\$ 6$ per year for the lowest income households (when valued at one-third of the residential function) to $\$ 87$ per year for households in the highest income group. As a percentage of income, however, benefits are approximately equal $(0.3 \%)$ for all seven groups.

Residence and workplace benefits are aggregated in Table $\mathrm{V}$ for the two renter cases presented previously, assuming in both examples that worker benefits are valued at one-third of residence benefits. Under the full capitalization assumption, dollar benefits vary from $\$ 52$ for households earning less than $\$ 3000$ per year to $\$ 213$ for households earning more than $\$ 25,000$. Total benefits are pro-poor when expressed as a percentage of household income, decreasing from $2.9 \%$ for the lowest income group to $0.71 \%$ for the highest income group. Benefits are more pro-poor if no capitalization takes place: while dollar benefits rise from $\$ 96$ per year for the lowest income group to $\$ 168$ per year for the highest income group, they fall from 5.3 to 0.56 as a percentage of income. In summary, benefits under the auto emissions control strategy are clearly pro-poor when calculated using the willingness-to-pay function obtained from the housing value approach.

\section{Valuing Health Benefits}

Automobile pollutants have been associated with increased mortality rates, various respiratory and heart diseases, and minor but pervasive maladies such as headaches and eye irritation. ${ }^{17}$ While the relation between air pollution and illness and death rate is still uncertain, it is possible to make crude quantitative estimates of health damages and thus the benefits of pollution abatement. According to a recent National Academy of Sciences study, for example, the current set of automotive emission controls would generate approximately $\$ 1.7$ billion per year in health benefits for American households, ${ }^{18}$ and thus per

\footnotetext{
${ }^{17}$ Summaries of the health effects of automotive pollutants are contained in National Academy of Sciences [23], Harrison [13] (Appendix A), and Lave and Seskin [21].

${ }^{18}$ The range was set at between $\$ 360$ million and $\$ 3$ billion per year. See National Academy of Sciences [23], p. 360 .
} 
TABLE $\mathrm{V}$

Dollar Value of Total Benefits by Ineome Group ${ }^{a}$

\begin{tabular}{ccccccccc}
\hline \multicolumn{7}{c}{ Income group (000s) } \\
\cline { 2 - 9 } & $\$ 0-3$ & $\$ 3-5$ & $\$ 5-7$ & $\$ 7-10$ & $\$ 10-15$ & $\$ 15-25$ & $\$ 25+$ \\
\hline \multicolumn{7}{c}{ Resident Case I and Worker Case B } \\
Dollar value & 96 & 101 & 106 & 105 & 111 & 130 & 168 \\
$\%$ of income & 5.3 & 2.5 & 1.8 & 1.2 & 0.89 & 0.65 & 0.56 \\
& Resident Case II and Worker Case B & & \\
Dollar value & 52 & 61 & 72 & 97 & 131 & 167 & 213 \\
\% of income & 2.9 & 1.5 & 1.2 & 1.1 & 1.0 & 0.84 & 0.71 \\
\hline
\end{tabular}

${ }^{a}$ See Tables III and IV for definitions of Resident and Worker Cases.

capita benefits of approximately $\$ 8$ per year or $\$ 24$ per household. Bostonians should receive greater than average benefits because controls in Boston are likely to produce greater than average air quality inprovements.

Do these health benefits differ systematically by income group? If so, are they distributed in favor of the rich or the poor? While we lack sufficient data to answer these questions with confidence, we can outline the factors that determine whether health benefits will be pro-rich or pro-poor and use available health information to provide illustrative estimates.

Consider the value of reductions in illness rates due to lower air pollution levels. The annual dollar benefit an individual receives depends upon the number of days of relief gained and the average valuc he places on a day of relicf. Both factors probably vary with income, but in opposite directions. The average person-days each individual gains from emission controls will depend on the air quality improvement he experiences as well as on such factors as the pre-control air quality, ${ }^{19}$ the individual's age, and his physical condition, particularly the presence of chronic diseases that might be worsened by higher air pollutant levels. Most studies indicate that air pollution exposure tends to aggravate existing conditions rather than induce illness in healthy individuals; the exceptions are minor ailments such as eye irritation, chest discomfort, cough and headaches, which are linked to photochemical oxidants. ${ }^{20}$ The elderly are especially vulnerable because their physical condition is worse and their recuperative powers are weaker. Since low income households would receive on average a greater improvement in air quality and since a higher proportion of low income individuals are elderly and in poor physical condition, ${ }^{21}$ the average number of person-days gained by the poor should be greater than that gained by the rich.

Low income households may value relief from illness less highly, however, because health is very likely a superior good whose value increases with income.22 That is, the poor are likely to be willing to pay considerably less than the rich

\footnotetext{
- 19 The pre-control level is relevant because the relationship between air pollution and illness (the dose-response curve) may be non-linear.

${ }^{20}$ See, for example, National Academy of Sciences [23] and U. S. Environmental Agency [38].

${ }^{21}$ In $1970,16.3 \%$ of the aged (65 and older) were poor, compared to 11.1 percent poor in the entire population. See U. S. Bureau of the Census [36]. See Lave and Seskin [21] for evidence of the elderly's greater vulnerability to air population.

${ }^{22}$ See Pauly [25] for a discussion of the effect of income on the demand for health care.
} 
for a given number of days of relief from illness. It seems very likely that those with high incomes would place a greater dollar value on the basis of four factors that influence willingness to pay : treatment costs would be easier to bear; relief from pain and suffering is probably a superior good for which the rich would pay more; earnings are greater and thus earnings losses from an illness would be greater; and the value of leisure should be greater. Becker has developed a theory of the allocation of time which provides a theoretical structure for valuing leisure time. ${ }^{23}$ Traditional theory equates the marginal value of leisure time with the wage rate on the assumption that individuals decide on their working time so as to maximize their utility, which implies that the marginal value of an hour at leisure is equal to the wage rate. Becker disentagles leisure by considering individual demands for leisure activities. Arguing that the rich value leisure more highly than the poor in this framework is equivalent to postulating that the demand functions for leisure activities have positive income elasticities, a plausible assumption. The elderly would thus be expected to place a lower dollar value on illness prevention because their demand for the leisure activities that would be interrupted by illness is lower than that of younger, more active persons.

The same opposing factors-greater relief from illness for the poor but higher value placed on health by the rich-relate to reduced death rates from air quality improvements. Mortality rates should decline more among lower income groups since they are older, less able to pay for preventive care, and more commonly suffer chronic diseases which, when aggravated by air contaminants, result in death. Analyzing the willingness to pay for reductions in death rates is problematical, but the results is almost certainly the same as with the willingness to pay for relief from illness. Low income households are probably less risk averse than high income households and thus less willing to pay for reduced risk of death. Moreover, there are more older persons in the low income group who, having less time to live and fewer dependents, may value decreases in the risk of death less highly than the young. ${ }^{24}$

The distribution of both morbidity and mortality benefits from air pollution control may be either pro-poor or pro-rich, depending upon the relative variations in physical benefits and in willingness to pay by income group. While to our knowledge there have been no studies which provide firm estimates of the net effect of these factors, we have used information from various sources to calculate crude death benefit estimates by income group. These figures are used solely to suggest the empirical significance of these two competing effects.

The National Academy of Sciences estimated the average change in the death rate following a $10 \%$ decrease in NOX concentrations (the average NOX decrcasc in the Boston arca from the automotive emission control strategy) to be approximately 2.3 deaths per 100,000 population..$^{25}$ Recent reanalysis of the data

${ }^{23}$ See Becker [4]. An illustration of the use of Becker's framework to value better health is given in Bishop and Cicchetti [5].

${ }^{24}$ Freeman [11] obtains the opposite result in his theoretical model-that older people would value decreases in the risk of death more highly than the young. Freeman's model distinguishes controllable and uncontrollable causes of death. Since the probability of dying from an uncontrollable cause increases with age, the marginal willingness to pay for a decrease in a controllable cause of death increases with age, other things equal, in this model.

${ }^{25}$ National Academy of Sciences [23], p. 356. We are grateful to Eugene Seskin for pointing out a typographical error in the NAS report, which reported $0.025 \%$ reduction in the total mortality rate following a $10 \%$ change in NOX concentration. The correct figure is $0.25 \%$. Since the mean 
TABLE VI

Sample Calculations of Dollar Health Benefits by Income Group

\begin{tabular}{|c|c|c|c|c|c|c|c|c|}
\hline & \multicolumn{7}{|c|}{ Income group $(000 \mathrm{~s})$} \\
\hline & & $\$ 0-3$ & $\$ 3-5$ & $\$ 5-7$ & $\$ 7-10$ & $\$ 10-15$ & $\$ 15-25$ & $\$ 25+$ \\
\hline (1) & $\begin{array}{l}\text { Bronchitis rate }^{a} \\
\quad(\text { illness } / 1000)\end{array}$ & 39.5 & 35.0 & 31.0 & 32.3 & 32.6 & 30.8 & 30.8 \\
\hline (2) & $\begin{array}{l}\text { Estimated mortality } \\
\text { benefit } \\
\text { (deaths } / 100,000 \text { ) }\end{array}$ & 4.77 & 4.23 & 3.75 & 3.90 & 3.94 & 3.72 & 3.27 \\
\hline (3) & $\begin{array}{c}\text { Value of } 1 \text { unit }^{b} \\
\text { change (\$) }\end{array}$ & & & & & & & \\
\hline & $\begin{aligned} \epsilon & =1.0 \\
\epsilon & =0.5\end{aligned}$ & $\begin{array}{l}0.42 \\
1.22\end{array}$ & $\begin{array}{l}0.94 \\
1.48\end{array}$ & $\begin{array}{l}1.42 \\
1.70\end{array}$ & $\begin{array}{l}2.00 \\
2.00\end{array}$ & $\begin{array}{l}2.94 \\
2.48\end{array}$ & $\begin{array}{l}4.70 \\
3.36\end{array}$ & $\begin{array}{l}7.06 \\
4.54\end{array}$ \\
\hline (4) & $\begin{array}{c}\text { Mortality benefits } \\
\quad(\$ \text { per year })\end{array}$ & & & & & & & \\
\hline & $\begin{array}{l}\epsilon=1.0 \\
\epsilon=0.5\end{array}$ & $\begin{array}{l}2.00 \\
5.82\end{array}$ & $\begin{array}{l}3.98 \\
6.26\end{array}$ & $\begin{array}{l}5.33 \\
6.38\end{array}$ & $\begin{array}{l}7.80 \\
7.80\end{array}$ & $\begin{array}{r}11.58 \\
9.77\end{array}$ & $\begin{array}{l}17.48 \\
12.50\end{array}$ & $\begin{array}{l}26.26 \\
16.89\end{array}$ \\
\hline (5) & $\begin{array}{l}\text { Benefits as } \% \text { of } \\
\text { income }\end{array}$ & & & & & & & \\
\hline & $\boldsymbol{\epsilon}=1.0$ & 0.11 & 0.10 & 0.09 & 0.09 & 0.09 & 0.09 & 0.09 \\
\hline & $\epsilon=0.5$ & 0.32 & 0.16 & 0.11 & 0.09 & 0.08 & 0.06 & 0.06 \\
\hline
\end{tabular}

${ }^{a}$ Source: U.S. Department of Health, Education and Welfare [36, p. 15].

${ }^{b} \epsilon=$ elasticity of willingness to pay for mortality decreases with respeet to ineome.

suggests a somewhat greater impact: Lave and Seskin obtained estimates of 6.1 deaths per 100,000 for the unadjusted total mortaility rate and 4.0 deaths per 100,000 for the age-sex-race adjusted total mortaility rate. ${ }^{26}$ Table VI includes a set of sample calculations which translate the estimate of 4.0 deaths per 100,000 population into average dollars by income group. In the first row are average rates of chronic bronchitis (a respiratory ailment linked to NOX concentrations) for households in each income group, based on data collected by the Public Health Service. ${ }^{27}$ The second row presents the mortality benefits accruing to each income group, calculated by multiplying 4.0 deaths $/ 100,000$ by the ratio of each income group's bronchitis rate to the average illness rate for the seven groups (33.1). Because the incidence of bronchitis is higher among low income people, the resulting mortality benefits are pro-poor. The estimated mortality rate improvements range from 3.77 deaths $/ 100,000$ for the two highest income groups to 4.77 deaths $/ 100,000$ for the lowest income group. Note that these figures may understate the degree of pro-poor distribution of mortality benefits because they ignore the greater improvements in air quality received by the poor.

The most common method used to value postponements in death (reductions in death rates) is to estimate the resources lost to society from premature death. ${ }^{28}$

total mortality rate for the sample was 912 per 100,000, the $10 \%$ reduction in NOX gives rise to a reduction of approximately 2.3 deaths $/ 100,000$.

${ }^{26}$ Lave and Seskin [21], reported to us in correspondence with Eugene Seskin prior to publication.

${ }^{27}$ U. S. Department of Health, Education and Welfare [37].

${ }^{28}$ Useful reviews of many of these issues are contained in Bishop and Cicchetti [5] and Raiffa, Schwartz, and Weinstein [26]. 
Dorothy Rice has provided the most complete estimates of the costs associated with both death and disease, based primarily or medical expenses (doctor's bills, hospital charges, medication costs and the like), and the individual's earnings had his or her life been prolonged. ${ }^{29}$ The value for an individual life saved using this approach has typically been in the range of $\$ 150,000$ to $\$ 250,000$. One issue of debate is whether the present value of the decendent's future consumption should be subtracted from the foregone future earnings to obtain a "net benefit to society." 30 The logic of calculating society's interest in the individual's longevity implies that net earnings are relevant, but the implications of this measure - that the individual's welfare should not count-scem counter-intuitive at bcst. This entire approach, moreover, rests on shaky economic and philosophical grounds: using earnings to measure the value of reducing death rates implies that society does not wish to prolong the lives of retired people or those unable to work; indeed, in their extreme, these calculations imply that society would be better off if we hastened their deaths. The economic objection to gross earnings as a measure of the benefits of prolonged life is that it does not relate to the demand of individuals for survival. As Schelling and Mishan have pointed out, the appropriate measure for programs which prolong life is a measure of the individual's willingness to pay for the reduced risk of death. ${ }^{31}$

Despite its theoretical appeal, however, willingness to pay is difficult to estimate empirically. In the handful of studies in this area, two general approaches have been used. Acton [2] estimates a value for a life saved of $\$ 28,000$ and $\$ 43,000$ (1970 dollars) based on responses to a questionnaire for willingness to pay for an ambulance program decreasing the risk of death by $1 / 500$ and $1 / 1000 .{ }^{32}$ His regression results imply an income elasticity of willingness to pay for the risk reduction which lies between approximately 0.5 and $1.0 .^{33}$ While the values for a life saved obtained by Acton seem quite small, the average value obtained by Jones-Lee [19] seems very large. Jones-Lee obtained an average value of an anticipated savings of one (anonymous) life of about $£ 3$ million (1974 pounds), or approximately $\$ 6$ million. ${ }^{34}$

Questionnaire studies of this type are difficult to evaluate since they depend upon confidence that respondents understood the questions and gave meaningful answers. Reductions in risk of death produced by public programs, including air pollution control programs, are extremely small -in the range of 5 to 10 deaths per 100,000 population - and it is not clear that most respondents can comprehend such small changes in low probabilities. Moreover, it is possible that the respondent would act differently if he were actually to pay for the reduced risk, either directly or through a tax increase.

The sccond technique for estimating willingness to pay for lowered risk of death uses information from the labor market. Since some workers such as miners, guards, and lumbermen face greater than average risk of death, wage differentials may provide an indirect measurement of the value individuals place on reducing risks. Thaler and Rosen [34] estimated that workers were on the average com-

${ }^{29}$ See Rice [27] and Rice and Cooper [28].

${ }^{30}$ This debate is summarized in Bishop and Cicchetti [5].

31 See Schelling [30] and Mishan [22].

${ }^{32}$ See Acton [2], p. 109.

${ }^{33}$ These figures represent the elasticities evaluated at the mean for the regression equations reported in Acton [2], pp. 92-98.

${ }^{34}$ Jones-Lee [19], p. 139. 
pensated an extra $\$ 200$ per year for an increased death rate of 0.001 per year, implying a value of life of $\$ 200,000 .^{35}$ Using a similar methodology, the same wage data, but different data on occupational risks, Smith [31] obtained a value of saving a life of around $\$ 2.6$ million. While both results are tentative, the Thaler and Rosen figures provide the more believable estimates of the quantitative willingness to pay for reducing the risk of death, which they argue is based on their superior data on death rates by occupation.

In the third row of Table VI are hypothetical dollar values for a one-unit (1 death $/ 100,000$ ) change in the risk of death based on this scant empirical evidence. A household earning $\$ 8,500$ per year (1970 dollars) is assumed to value the reduction at $\$ 2.00$, which implies a statistical value of life of $\$ 200,000$, the figure obtained by Thaler and Rosen. Results are presented for values of the income elasticity of willingness to pay of unity (i.e., the average household in the $\$ 3000$ to $\$ 4999$ category will value a one-unit change only $40 / 85$ as much as the average household in the $\$ 7000$ to $\$ 9999$ category, or at $\$ 0.94$ ) and 0.5 , approximately the range found by Acton in his study of the willingness to pay for reductions in the risk of death from heart attack. The estimated dollar value of mortality benefits using these average valuation figures are given in the fourth row. Assuming an elasticity of 1.0, the dollar values range from around $\$ 2$ for the lowest income group to $\$ 26$ for the highest income group; as a percentage of income, however, the benefits are pro-poor, ranging from $0.11 \%$ for the lowest income group to $0.09 \%$ for the highest. Benefits are much more pro-poor if the income elasticity is 0.5 : dollar benefits range from $\$ 6$ to $\$ 17$ and percentage benefits from $0.32 \%$ to $0.06 \%$.

Reduced illness benefits are probably less pro-poor than death risk benefits. Acute respiratory diseases, such as the colds and sore throats that are often associated with pollution exposure, are less skewed to the poor than are the chronic diseases we used to proxy increased risk of death. ${ }^{37}$ Moreover, high income persons probably value minor incapacities more highly than low income persons. If person-days are approximately equal for all income groups and if the income elasticity of the valuation of such days is substantially greater than unity, illness benefits would be pro-rich even when expressed as a percentage of income.

\section{CONCLUSION}

We deliberately do not combine the housing market and health estimates of auto emission control benefits to Boston residents. For one thing, our illustrative health figures only relate to death risk benefits, not the benefits of reduced days of discomfort (and expense) due to illness. Moreover, even with complete health estimates it would be difficult to determine the overlap between the two approaches. Regardless of how much the two approaches overlap, however, our results make it clear that while the physical benefits of improved urban air quality at one's residence are substantially pro-poor, monetary benefits are less so. Moreover, our results indicate that when workplace benefits are included in the analysis, both the physical and monetary benefits of auto emission controls become less pro-poor.

\footnotetext{
${ }_{35}$ Thaler and Rosen [34], p. 294.

${ }^{36}$ Smith [31], p. 91.

${ }^{37}$ Of course, the poor may suffer a longer illness because of inadequate medical attention or deficient nutrition and recuperative powers.
} 
In terms of the housing market valuation, the extent to which the progressivity of benefits is diminished when dollar values are used depends upon the income elasticity of demand for clean air determined by the willingness-to-pay function and upon the assumptions made about the capitalization of air quality improvements in higher rents. If a substantial portion of renter benefits eventually accrues to landlords, the final distribution of benefits will be substantially less pro-poor. The effect of monetizing health benefits is problematic because low income households incur the greatest reductions in illness and mortality, but they also presumably place a lower monetary value on both. We tentatively conclude that the monetary value of health benefits is substantially less pro-poor than the physical benefits, with the extent of difference depending upon the income elasticity of demand for good health.

\section{APPENDIX}

The two tables in the Appendix provide information on the data used in this study. Table VII gives the definition and the source of the underlying data referred to in the paper. Table VIII summarizes the data used to estimate benefits to owners and renters in the study.

\section{TABLE VII}

Description of Data Sources

\begin{tabular}{|c|c|c|}
\hline Variable & Definition & Source \\
\hline$H$ & $\begin{array}{l}\text { Number of housing units by tenure } \\
\text { and income group (See Table VIII) }\end{array}$ & $\begin{array}{l}1970 \text { U.S. Census, Census Tracts, Final } \\
\text { Report PHC (1)-29, Boston, Mass. } \\
\text { SMSA, Table P-4. }\end{array}$ \\
\hline $\operatorname{NOX}^{b}$ & $\begin{array}{l}\text { Base level concentration of nitrogen } \\
\text { oxides }\end{array}$ & TASSIM : See Ingram and Fauth $[16]$. \\
\hline NOX ${ }^{c}$ & $\begin{array}{l}\text { Control level concentration of } \\
\text { nitrogen oxides }\end{array}$ & TASSIM : See Ingram and Fauth $[16]$ \\
\hline $\mathrm{HT}$ & $\begin{array}{l}\text { Fraction of households by family type } \\
\text { category }\end{array}$ & $\begin{array}{l}1970 \text { U.S. Census, Detailed Characteristics, } \\
\text { Final Report PC (1)-D23, Mass., } \\
\text { Table 165. }\end{array}$ \\
\hline $\mathrm{EM}$ & Number of employees by job category & $\begin{array}{l}\text { Massachusetts Division of Employment } \\
\text { Security. }\end{array}$ \\
\hline FAM & $\begin{array}{l}\text { Fraction of employees by family type, } \\
\text { job category and income group }\end{array}$ & $\begin{array}{l}1970 \text { U.S. Census, Detailed Characteristics, } \\
\text { Final Report PC (1)-D23, Mass., } \\
\text { Tables } 194 \text { and } 204 .\end{array}$ \\
\hline$A$ & $\begin{array}{l}\text { Fraction of rental units owned by } \\
\text { ineome group (see Table VIII) }\end{array}$ & $\begin{array}{l}1970 \text { U.S. Census, Detailed Characteristics, } \\
\text { Final Report PC (1)-23, Mass., } \\
\text { Tables } 198 \text { and 203; Sternlieb [33] } \\
\text { Sternlieb [34]. }\end{array}$ \\
\hline TU & Total rental units in Boston SMSA & $\begin{array}{l}1970 \text { U.S. Census, Census Tracts, Final } \\
\text { Report PHC (1)-29, Boston, Mass., } \\
\text { SMSA, Table P-4. }\end{array}$ \\
\hline WA & $\begin{array}{l}\text { Average willingness to pay for air } \\
\text { quality improvements for all renter } \\
\text { households }\end{array}$ & Harrison and Rubinfeld [15]. \\
\hline
\end{tabular}




\section{TABLE VIII}

Housing Units and Rental Unit Ownership by Income Group in the Boston SMSA

\begin{tabular}{|c|c|c|c|c|c|c|c|}
\hline & \multicolumn{7}{|c|}{ Income group $(000 \mathrm{~s})$} \\
\hline & $\$ 0-3$ & $\$ 3-5$ & $\$ 5-7$ & $\$ 7-10$ & $\$ 10-15$ & $\$ 15-25$ & $\$ 25+$ \\
\hline \multicolumn{8}{|c|}{ Housing units by tenure ${ }^{a}$} \\
\hline Owners & 34,539 & 25,351 & 30,652 & 68,214 & 132,247 & 115,860 & 44,727 \\
\hline Renters & 82,092 & 52,683 & 57,735 & 80,929 & 77,670 & 36,495 & 7,698 \\
\hline Total & 116,631 & 78,034 & 88,387 & 149,143 & 209,917 & 152,355 & 52,695 \\
\hline \multicolumn{8}{|c|}{ Percentage of rental units owned ${ }^{b}$} \\
\hline & 7.5 & 5.4 & 6.9 & 17.0 & 30.1 & 24.2 & 8.5 \\
\hline
\end{tabular}

a Source: 1970 U.S. Census, Census Tracts Final Report PHC (1)-29, Boston, Mass. SMSA, Table p-4.

${ }^{b}$ Source: 1970 U.S. Census, Detailed Characteristics, Final Report PX (1)-23, Massachusetts, Tables 198 and 203; and Sternlieb [33] and Sternlieb [34]. Details are available from the authors upon request.

\section{REFERENCES}

1. J. P. Acton, Evaluation of a life-saving program : the case of heart attacks. Unpublished Ph.D. dissertation, Harvard University (1970).

2. J. P. Acton, Evaluating public programs to save lives: the case of heart attacks, Research Report R-73-02, Rand Corporation, Santa Monica, California (1973).

3. J. P. Acton, Measuring the social impact of heart and circulatory disease programs: preliminary framework and estimates, Research Report R-75-02, Rand Corporation, Santa Monica, California (1975).

4. G. R. Becker, A theory of the allocation of time, Econ J. 75, 493-516 (November 1965).

5. J. Bishop and C. Cicchetti, Some institutional and eonceptual thoughts on the measurement of indirect and intangible benefits and costs, in "Cost Benefit Analysis and Water Pollution Policy" (Peskin and Seskin, Eds.), The Urban Institute, Washington (1975).

6. Council on Environmental Quality, "Environmental Quality: The Second Annual Report of the Council on Environmental Quality," U. S. Government Printing Office, Washington (August 1971).

7. D. N. Dewees, "Foconomirs and Public Policy: The Automobile Pollution Case," MIT Press, Cambridge, Mass. (1974).

8. N. S. Dorfman and A. Snow, Who will pay for pollution control? Nat. Tax J. 28, 101-115 (1976).

9. R. Dorfman, Incidence of the benefits and costs of environmental programs, Amer. Econ. Rev. 67, 333-340 (1977).

10. A. M. Freeman, The distribution of environmental quality, in "Environmental Quality Analysis" (A. V. Kneese and B. T. Bower, Eds.), The Johns Hopkins Press, Baltimore, Maryland (1972).

11. A. M. Freeman, Some extensions of a simple value of life saving model, Discussion Paper D-19, Resources for the Future, Washington, D.C. (October 1977).

12. F. P. Grad et al., "The Automobile and the Regulation of Its Impact on the Environment," University of Oklahoma Press, Norman, Okla. (1975).

13. D. Harrison, Jr., "Who Pays for Clean Air: The Cust and Benefit Distribution of Federal Automobile Emission Standards," Ballinger Publishing Company, Cambridge, Mass. (1975).

14. D. Harrison, Jr., Controlling automotive emissions: how to save more than $\$ 1$ billion per year and help the poor too, Pub. Pol. 25, 527-553 (Fall 1977).

15. D. Harrison Jr., and D. L. Rubinfeld, Hedonic housing prices and the demand for clean air, J. Envir. Manag. 5, 81-102 (1978).

16. G. K. Ingram and G. R. Fauth, "TASSIM: A Transportation and Air Shed Simulation Model.' Final Report to the U.S. Department of Transportation, Springfield, Va. : National Technical Information Service (May 1974). 
17. H. D. Jacoby et al., "Clearing the Air: Federal Policy on Automotive Emission Control," Cambridge, Mass.: Ballinger Publishing Company (1973).

18. M. W. Jones-Lee, The value of changes in the probability of death or injury, J. Pol. Econ. $82,835-849$ (1974).

19. M. W. Jones-Lee, "The Value of Life: An Economic Analysis," University of Chicago Press, Chicago (1976).

20. W. J. Kruvant, People, energy, and pollution, in "The American Energy Consumer" (D. K. Newman and D. Day, Eds.), Ballinger Publishing Company, Cambridge, Mass. (1975).

21. L. B. Lave and E. P. Seskin, "Air Pollution and Human Health," Johns Hopkins University Press, Baltimore (1977).

22. E. J. Mishan, Evaluation of life and limb: A theoretical approach, J. Pol. Econ. 66, 687-705 (1971).

23. National Academy of Sciences, "Air Quality and Automobile Emission Control," Vol. 4, "The Costs and Benefits of Automobile Emission Control," U. S. Government Printing Office, Washington (1974).

24. J. P. Nelson, Residential choice, hedonic prices, and the demand for urban air quality, $J$. Urb. Econ., 5, 357-369 (1978).

25. M. V. Pauly, Economic aspects of consumer use, in "Consumer Incentives for Health Care" (S. J. Muchkin, Eds.), Prodist, New York (1974).

26. H. Raiffa, W. B. Schwartz and M. C. Weinstein, Evaluating health effects of societal decisions and programs, in "Decision-Making in the Environmental Protection Agency," prepared for the Committee on Environmental Decision-Making, National Research Council, National Academy of Sciences, Washington (1977).

27. D. Rice, Estimating the cost of illness, Amer. J. Pub. H. 57, 424-440 (1967).

28. D. Rice and B. Cooper, The economic value of human life, Amer. J. Pub. H. 57, 1954-1966 (1967).

29. D. L. Rubinfeld, Market approaches to the measurement of the benefits of air pollution abatement, in "Air Pollution and Administrative Control" (A. F. Friedlaender, Ed.), MIT Press, Cambridge, Mass. (1978).

30. T. C. Schelling, The life you save may be your own, in "Problems in Public Expenditure Analysis" (Chase, Ed.), The Brookings Institution, Washington (1968).

31. R. S. Smith, "The Occupational Safety and Health Act: Its Goals and Its Achievements," American Enterprise Institute for Public Policy Research, Washington (1976).

32. G. Sternlieb, "The Tenement Landlord," Rutgers University Press, New Brunswick, N. J. (1969).

33. G. Sternlieb, "The Urban Housing Dilemma," Office of Rent Control, New York (1972).

34. R. H. Thaler and S. Rosen, The value of saving a life: Evidence from the labor market, in "Household Production and Consumption" (Terleckyj, Ed.), Columbia University Press, New York (1976).

35. U. S. Bureau of the Census, "Census of Population and Housing: 1970," Census Tracts, Final Report PHC (1)-29 Boston, Mass. SMSA, U. S. Government Printing Office, Washington (1972).

36. U. S. Bureau of the Census, "Current Population Report: Characteristics of the Low-Income Population," U. S. Government Printing Office, Washington (1973).

37. U. S. Department of Health, Education and Welfare, "Prevalence of Selected Chronic Respiratory Conditions-1970," DHEW Publication No. (HRA) 74-1511, U. S. Government Printing Office, Washington (September 1973).

38. U. S. Environmental Protection Agency, "Air Quality Criteria for Nitrogen Oxides," U. S. Government Printing Office, Washington (1971).

39. J. M. Zupan, "The Distribution of Air Quality in the New York Region," The Johns Hopkins University Press, Baltimore, Md. (1973). 